\title{
Assessment of in vitro genotoxicity effect of homosalate in cosmetics
}

\section{Selma YAZAR ${ }^{1}{ }^{*}$, Yaman GÖKÇEK ${ }^{2}$}

1 İstanbul Yeni Yüzyıl University, Faculty of Pharmacy, Department of Pharmaceutical Toxicology, İstanbul, Turkey.

2 SAKO Plastic Industry Trade Inc., Yenidoğan Mah. Şehit Naci Çakar Sok. 4/1, 34030, Bayrampaşa, İstanbul, Turkey.

* Corresponding Author. E-mail: selma.yazar@yeniyuzyil.edu.tr (S.Y.); Tel. +90-212-444-50-01; ORCID No: 00000003-2626-4066

Received: 10 November 2017 / Revised: 11 January 2018 / Accepted: 17 January 2018

ABSTRACT: Many cosmetics contain UV filters as active ingredients for skin protection. Homosalate (HMS) is one of the most widely used organic UV filter. Despite the widespread use of these products, data about their genotoxic effects are lacking. Genotoxicity assessment is an important part of biosafety evaluation; therefore, we aimed to investigate genotoxic effects of homosalate as organic UV filter. The cytotoxicity effects of homosalate were assessed by trypan blue exclusion. Homosalate was incubated with four different concentrations for $30 \mathrm{~min}$ and $120 \mathrm{~min}$. Our results revealed that HMS increased the DNA migration both the time and concentration manner. DNA damage was higher in cells that had been incubated with the greatest concentration of $200 \mu \mathrm{g} \mathrm{mL}-1(p<0.05)$. Results obtained by the present study indicate that homosalate would be genotoxic at higher concentration and incubation time. Further studies should be carried out with different test systems (in vivo and in vitro) related to its genotoxic effects and incubation time should be extended. This may be helpful for genotoxicity evaluation of compounds with similar characteristics and their impact of human population.

KEYWORDS: Comet assay; homosalate; DNA damage; genotoxicity.

\section{INTRODUCTION}

Organic UV filters protect human skin from UV radiation and prevent light-induced product degradation in many cosmetic products such as lipsticks and lip balms, make-up, perfumes, facial creams, aftershaves, hand creams, face powders and hairsprays by absorbing UV light [1]. UV filters are divided in three types: organic (chemical), inorganic (mineral, physical) and insoluble organic pigments [2]. Inorganic UV filters comprise of particles that act by scattering, reflecting or absorbing the passage of UV radiation [3]. Organic UV filters are able to absorb UV rays through chemical reactions, whereas inorganic UV filters incident UV radiation and their importance increases day by day due to negative effects of UV radiation and skin cancer. Generally, organic and inorganic UV filter combinations are used to achieve a sufficient Sun Protection Factor [4].

Increasing application of these substances in all age groups brings with the responsibility against healthcare, economy and environment [5]. Nowadays, there is a growing concern regarding the safety of organic UV filters, mainly when applied on the skin in variable conditions. It is also reported that some skinabsorbed UV filters could result unknown systemic toxic effects [6]. However, recent studies have shown that organic UV filters in certain formulation -after absorption through the skin- have the potential of being metabolized and excreted $[7,8]$. Now that many organic UV filters are lipophilic, they can easily bioaccumulate and biomagnify in aquatic ecosytems, where their impact is a big concern. These persistent chemicals have been determined in various water samples [9], fish [10] and several biological samples of human such as breast milk [11] and placenta [12]. Therefore they should be considered as environmental contaminants.

Although the acute and subchronic toxicities of these compounds are considered to be rather low; their long-term exposure may result in various adverse and serious health effects like mutagenicity, genotoxicity, ontogeny, endocrine disruptors, and photoallergic reactions $[2,13]$.

How to cite this article: Yazar S, Gökçek Y. Assessment of in vitro genotoxicity effect of homosalate in cosmetics. Marmara Pharm J. 2018; 22 (3): 436-442. 
Organic UV filters are often classified as 7 group; 1-Anthranilates, 2-benzophenones, 3-camphors, 4cinnamates, 5-dibenzoylmethanes, 6-p-aminobenzoates 7- salicylates [13]. Among these saliciylates, 3,3,5trimethylcyclohexyl 2-hydroxybenzoate (homosalate- HMS) can be found in many products (Figure 1) [7]. The content of UV filters in products are regulated by EU Cosmetic Directive and according to Directive 76/768/EEC, the maximum allowed concentration of HMS in cosmetic products can be $15 \%$ in the United States, Australia and 10\% in the European Union (EU), Korea and Japan [14, 15].

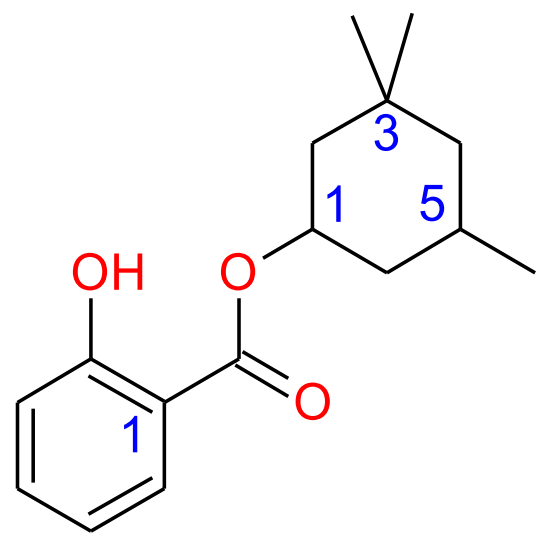

Figure 1. The Chemical structure of homosalate.

As a member of salicylate-type UV filters, HMS contains an ester bridge between phenol and alkylsubstituted cyclohexane rings. Its unique ortho-disubstituted chemical structure provides an important advantage for this molecule of being chosen as a stable ingredient in UV filter formulations for more than fifty years [16]. The genotoxic activities of phenolics [17, 18], esters [19, 20] and cyclohexane [21] were previously reported. The presence of alkyl-substituted cyclohexane ring can drastically change the lipophilicity of the whole molecule, might possibly have big impact on ADME (absorption, distribution, metabolism, excretion) [22] and as well as toxicity properties. In addition, toxicological profile of HMS has been reviewed recently [23].

Although the daily consumption of UV filters is low, the long-term exposure to organic UV filters can cause to serious toxic effects including mutations and DNA damage [24]. DNA damage induced by mutagens can play a key role in the process of carcinogenesis and inherited genetic diseases [25]. DNA damage can occur through a variety of processes including electron transfer, hydrogen abstraction, triplet-triplet energy transfer, or generation of reactive oxygen species. Formation of so-called DNA adducts may result in teratogenesis, mutagenesis and carcinogenesis [26]. Genotoxicity is the capability of a chemical to alter the genetic material of the cell, and is one of the earliest effects of most carcinogens [2].

Despite the widespread use of HMS, data about their genotoxic effects are lacking. Therefore, in this study, the potential genotoxic effect of HMS has been evaluated using the single cell gel electrophoresis (SCGEcomet) assay in isolated human peripheral lymphocytes. This study provides directly toxicity data beneficial for the evaluation of potential risk of HMS for both ecology and human health.

\section{RESULTS}

In the experiments, human peripheral blood lymphocytes were exposed to different concentrations (10, 50, 100 and $200 \mu \mathrm{g} \mathrm{mL}^{-1}$ ) of HMS for 30 and $120 \mathrm{~min}$ after treatment, cell viability was determined by using the trypan blue exclusion method and it was found to be above $90 \%$ for all samples. The data indicate that all concentrations of HMS did not produce statistically significant differences in cell viability when compared to control $(\mathrm{p}>0.05)$. According to the data obtained from three separate experiments, DNA damage was significantly increased at $200 \mu \mathrm{g} \mathrm{mL}^{-1}$, compared with those of untreated cells. The increase was dose dependent.

Exposure to all concentrations of HMS for 120 min caused significant increases in the experiment. The toxicity of HMS at 10, 50 and $100 \mu \mathrm{g} \mathrm{mL}-1$ concentration was not statistically significant $(p>0.05)$. The cell viability percentage of lymphocytes after exposure to increasing concentrations of homosalate for 30 and 120 min is shown in Figure 2. 
The results of in this study revealed that HMS increased the DNA migration in both concentration and time dependent manner. DNA damage was higher in cells which had been incubated with $200 \mu \mathrm{g} \mathrm{mL}^{-1}$ and $120 \mathrm{~min}(\mathrm{p}<0.05)$. The cell viability percentage and total comet scores (TCS) in lymphocytes after exposures of homosalate are shown Table1.

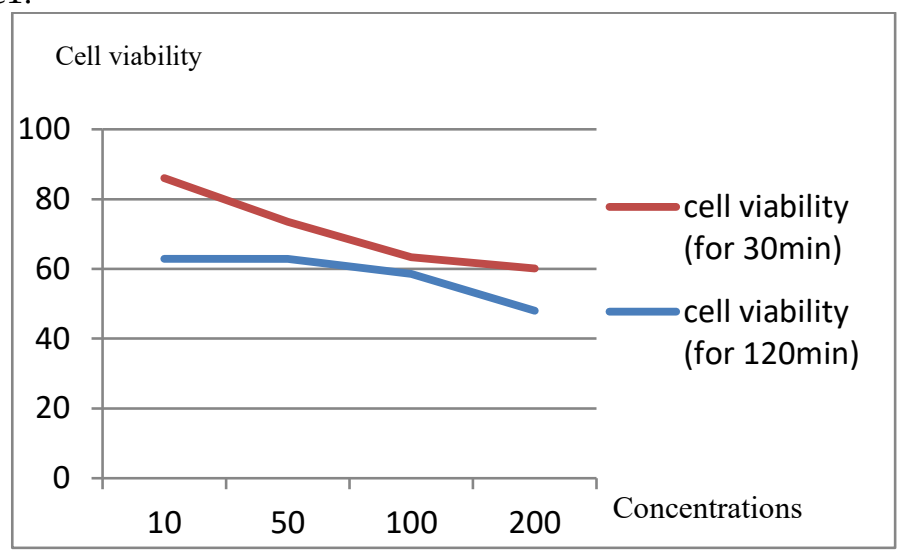

Figure 2: Cytotoxicity in lympocytes after exposures to increasing concentrations of HMS for 30 and 120 min

Table 1: Cell viability percentage and total comet scores in lymphocytes after exposures of HMS at different concentrations for 30 and $120 \mathrm{~min}$

\begin{tabular}{|c|c|c|c|c|}
\hline Samples & $\begin{array}{l}\text { Time } \\
(\min )\end{array}$ & $\begin{array}{l}\text { Concentration } \\
\left(\mu \mathrm{g} \mathrm{mL}^{-1}\right)\end{array}$ & $\begin{array}{l}\text { Cell viability \% } \\
(\text { Mean } \pm \text { SD) }\end{array}$ & TCSa (Mean $\pm S D)$ \\
\hline $\begin{array}{l}\text { Negative control } \\
\text { (DMSO) }\end{array}$ & 30 & 10 & $91.80 \pm 1.20$ & $15.30 \pm 2.34$ \\
\hline Positive control $\left(\mathrm{H}_{2} \mathrm{O}_{2}\right)$ & 30 & 25 & $90.79 \pm 5.12$ & $156.1 \pm 2.23$ \\
\hline \multirow[t]{4}{*}{ HMS } & 30 & 10 & $86.01 \pm 7.3$ & $50.20 \pm 5.2$ \\
\hline & 30 & 50 & $73.51 \pm 1.20$ & $51.8 \pm 3.8$ \\
\hline & 30 & 100 & $63.30 \pm 3.12$ & $52.1 \pm 4.3$ \\
\hline & 30 & 200 & $60.11 \pm 5.28$ & $54.6 \pm 2.5$ \\
\hline \multirow[t]{4}{*}{ HMS } & 120 & 10 & $62.88 \pm 1.23$ & $50.12 \pm 4.5$ \\
\hline & 120 & 50 & $62.82 \pm 5.1$ & $55.89 \pm 9.1$ \\
\hline & 120 & 100 & $58.6 \pm 8.3$ & $57.31 \pm 3.4^{*}$ \\
\hline & 120 & 200 & $47.99 \pm 7.3$ & $68.1 \pm 1.2^{*}$ \\
\hline
\end{tabular}

aTCS $($ Total comet score) $=0 \times$ No Migration $+1 \times$ LowMigration $+2 \times$ MediumMigration $+3 \times$ High Migration $+4 \times$ Extensive Migration, ${ }^{*} \mathrm{p}<0.05$

\section{DISCUSSION}

Sunscreens are more likely prone to macroscopic tests (prevention of skin erythema and sunburns) rather than microscopic ones like genotoxicity, understanding the cellular level of protection against skin cancer [27]. UV filters are necessary to a through risk/benefit evaluation, which includes acute skin damage like sunburn, chronic skin damage such as DNA damage, photo induced immune suppression, reproductive toxicity, genotoxicity, carcinogenicity and mutagenesis. More, UV filters should be determined a strict toxicological safety evaluation prior to approval $[23,28]$.

Although the daily use of UV filters is low, the long-term exposure to UV filters can cause to genotoxic effects. There are very few studies about the genotoxic effects of organic UV filters [24, 29]. Despite the widespread use of HMS, a few studies are present about the in vivo and in vitro effects of HMS, data about their genotoxic effects in human are lacking [23]. To the best of our knowledge, we report here the first study involving human lymphocytes to assess the genotoxic effect of homosalate using comet assay. The study performed by Imamoviä et al. [30] about HMS's genotoxicity on plants seems to be the only work reported so far, in which the genotoxic effects of chlorinated homosalate by-products occurred in the presence of free chlorine using Allium test on onion root and they found genotoxic effects of HMS [30].

HMS is strongly lipophilic and the presence of alkyl-substituted cyclohexane ring on HMS can drastically change the lipophilicity of the whole molecule [22] and as well as toxicity properties. HMS may be attributed to high affinity binding to the lipophilic components of the skin layers. HMS absorb into the systemic circulation from skin after topical application of the gel formulation in rats [8]. Schlumpf et al. [10] 
also found residues of HMS in breast milk samples. Particularly, $15.09 \%$ of the study participants used the sunscreens containing HMS, and complied the use of products containing these UV with their presence in milk. Although the daily use of HMS-containing filters is low, the environmental problem caused from their long-term input should not be neglected [24].

The genotoxicity of benzophenones (BPs), widely used in UV filters, were tested using the SOS/UMU assay. These results of the study revealed that the major contributor to the genotoxicity of the PBs was the ortho, para-di-substitution and the increasing hydroxy substitution on the benzene ring. In addition, the higher the dispersion of the substituent species on the two benzene rings, the lower the genotoxicty exhibited by the compound [24]. HMS contains an ester bridge between phenol and alkyl-substituted cyclohexane rings [16]. The DNA damage observed in this work might possibly be due to free radical formation: a sunscreen (as RC-CR' where Rs are organic functional groups) will absorb solar photons having sufficient energy to be able to break numerous covalent bonds. Carbon-centered free radicals are quite reactive and can assault and change other molecules in the closest perimeter. In addition, since sunscreens will eventually meet molecular oxygen from air, these free radicals could possibly form organic peroxyl radicals. Hydrogen atom elimination, addition and electron transfer mechanisms are known to be the main pathways hydroxyl radical goes into reaction with organic compounds. As in homosalate, . OH may react with thymine (addition to a double bond) ending up with thymine radical and -with oxygen- thymine peroxyl radical. These reactions can possibly cause DNA damage over strand breakage, cell mutation, and finally, cell death [13]. Therefore; the chemical stabilization of HMS in any topical dosage form seems to be critical.

The latest study about organic UV filters' genotoxic effects was reported by Sharma et al. [2]. The genotoxic effects of ethylhexyl methoxycinnamate (EHMC), a member of organic UV filters, have been reported using both bioassays (SOS chromotest and Umu C test). The author was observed significant genotoxicity of EHMC at the highest concentrations. Afterwards, the genotoxic potential of EHMC was evaluated using the comet assay by measuring DNA damage on TK- 6 cell line (the human-derived lymphoblastoid) and HL1-hT1 (human adult stem cell). Both cell lines showed higher DNA damage by EHMC. The results of our study are in agreement with Sharma et al. [2]. Sevinc [31] reported the genotoxic effects of octocrylene and avobenzone alone and in combination using comet assay. The author reported that significant DNA damage was observed in higher concentrations of avobenzone and octocrylene. The level of DNA damage was higher with combination forms of these chemicals. Our results are in parallel with Sharma et al. [2] and Sevinc [31] UV filters may attack DNA either directly or indirectly by free radicals to produce damage in the form of adducts or cell death. According to these results, it has been suggested that UV filters may contribute to long term skin damage [13] and might represent a human hazard.

\section{CONCLUSION}

In coclusion; our study showed for the first time that, the potential genotoxic effect of HMS has been evaluated using the single cell gel electrophoresis (SCGE-comet) assay in isolated human peripheral lymphocytes. We conclude that based on the results of the comet assay, HMS has high potential to interact with DNA and to cause primary DNA damage in human lymphocytes as an in vitro model. However, further studies should be carried out with different test systems related to its genotoxic effects and incubation time should be extended. This may be beneficial for genotoxicity evaluation of compounds with similar characteristics and their impact of human population.

\section{MATERIALS AND METHODS}

\subsection{Reagents and chemicals}

HMS (CAS No: PHR1085) was supplied by Sigma. Other chemicals used in the comet assay were purchased from the following suppliers: low melting agarose (LMA), high melting agarose (HMA), Triton-X100, EDTA, ethidium bromide, histopaque-1077, phosphate-buffered saline (PBS) tablets were purchased from Sigma; sodium chloride $(\mathrm{NaCl})$, sodium hydroxide $(\mathrm{NaOH})$, dimethylsulfoxide (DMSO) from Merck.

\subsection{Blood samples and cell preparation}

For each experiment, $5 \mathrm{~mL}$ heparinized whole blood samples were collected by venipuncture from female author not exposed to radiation or dugs. The alkaline version of the comet assay was performed according to Singh et al. [32] with a minor modification. The triplicate experiments were provided by blood samples from the same donor at different time intervals. Peripheral blood lymphocytes were isolated by 
Histopaque 1077 density gradient centrifugation, washed with phosphate-buffered saline (PBS) and suspended in $1 \mathrm{~mL}$ PBS. Cell viability for isolated human lymphocytes was determined by trypan blue exclusion method and it was found to be above $90 \%$ for all samples. Lymphocytes were incubated with 10, 50, 100 and $200 \mu \mathrm{g} / \mathrm{mL}$ HMS and blank control at $37{ }^{\circ} \mathrm{C}$ for $30 \mathrm{~min}$ and for $120 \mathrm{~min}$ separately. Selected concentrations were similar to concentrations reported in previous studies [2, 24, 31]. Parallel with HMS, negative controls were set up at the same temperature and exposure time by incubating lymphocytes with DMSO (final concentration 1\%). Positive controls consisted of cells treated with $\mathrm{H}_{2} \mathrm{O}_{2}$ (final concentration $10 \mu \mathrm{M}$ ) were incubated at $37^{\circ} \mathrm{C}$ for 5 minutes. After incubation, the lymphocytes were mixed with $100 \mu \mathrm{L}$ of $0.7 \%(\mathrm{w} / \mathrm{v})$ low melting agarose, rapidly mounted on pre-coated microscopic slides covered with a coverslip and let $0.7 \%$ high melting agarose $(\mathrm{w} / \mathrm{v})$ solidify at $+4{ }^{\circ} \mathrm{C}$. Once coverslips were gently removed, the slides were immersed in an ice-cold freshly prepared lysis solution $(2.5 \mathrm{M} \mathrm{NaCl}, 100 \mathrm{mM}$ EDTA, $10 \mathrm{mM}$ Tris, $\mathrm{pH} 10$ with $1 \%$ Triton $\mathrm{X}-100$ and $10 \% \mathrm{DMSO}$ ) for at least $2 \mathrm{~h}$ at $+4{ }^{\circ} \mathrm{C}$. At the end of lysis process, the slides were placed in fresh electrophoresis buffer ( $5 \mathrm{M} \mathrm{NaOH}, 0.2 \mathrm{M} \mathrm{EDTA})$ and left for $20 \mathrm{~min}$ to allow DNA to unwind as well as labile alkali damage to be expressed. Electrophoresis was performed for $30 \mathrm{~min}$ at $300 \mathrm{~mA}$ and $15 \mathrm{~V}$ $+4{ }^{\circ} \mathrm{C}$ (ThermoEC MidiCell Primo, ABD; BioRad Power Pac, England). After electrophoresis, the slides were removed from the tank, gently washed 3 times for $5 \mathrm{~min}$ in fresh neutralization buffer $(0.4 \mathrm{M}$ tris, $\mathrm{pH} 7.5)$ in order to neutralize excess alkali. Slides were stained with $50 \mu \mathrm{L}$ of ethidium bromide $(20 \mu \mathrm{g} / \mathrm{mL})$ per each slide. $15 \mathrm{~min}$ after staining, the slides were evaluated at 200X objective on a fluorescence microscope (Olympus BX50, Optical Co. GmbH, Hamburg, Germany). The experiment was done in triplicate. For each sample, 100 cells (50 for each replicate slide) were analyzed. The damage is represented by an increase of DNA fragments that have migrated out of the cell nucleus during electrophoresis. Cells were graded by eye into five categories corresponding to the extent of DNA migration as described by Collins et al. [33]. Undamaged cells were defined as cells with an intact nucleus without a tail and damaged cells had the appearance of a comet as shown in Figure 3.

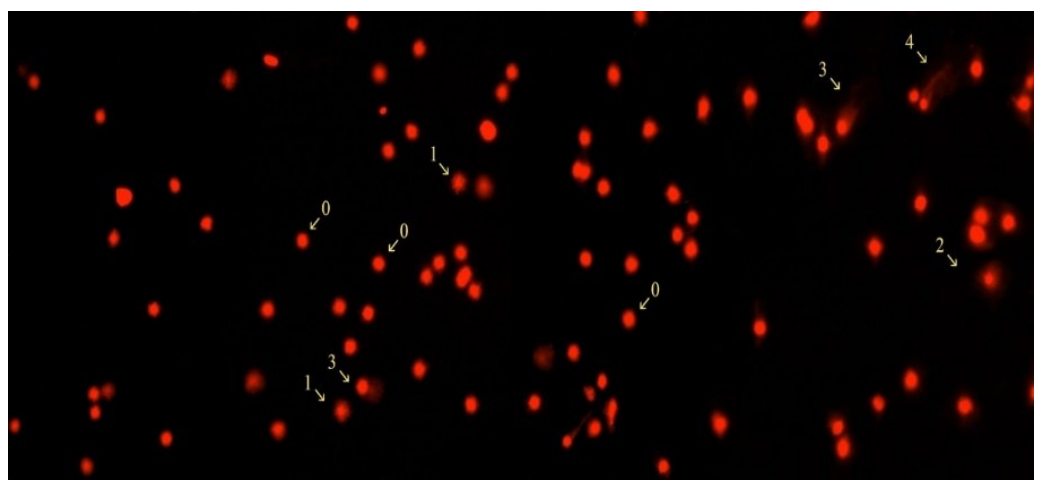

Figure 3. Lymphocytes were incubated with $200 \mu \mathrm{g} / \mathrm{mL}$ HMS for $120 \mathrm{~min}$. (0: No migration, 1:Low migration, 2:Medium Migration, 3:High Migration, 4: Extensive Migration)

DNA damage can be scored by using parameter total comet score (TCS). TCS was evaluated according to the following equation formula, migration

TCS $=0 \times$ nomigration $+1 \times$ low migration $+2 \times$ medium migration $+3 \times$ high migration $+4 \times$ extensive

\subsection{Statistical analysis}

The SPSS 20 was used for statistical analysis. Statistical comparision of the results from negative and positive controls and test groups treated with HMS were carried out by one-way analysis of variance (ANOVA). A non-parametric Kruskal Wallis test was used to determine whether DNA damages were statistically different from each other. 
Acknowledgements: Thanks to Prof. Türkan Yurdun for her supervising in this research. The authors declared that this study has received no financial support.

Author contributions: Concept - S.Y., Y.G.; Design - S.Y., Y.G.; Supervision - S.Y., Y.G.; Resource - S.Y., Y.G.; Materials - S.Y., Y.G.; Data Collection and/or Processing - S.Y., Y.G.; Analysis and/or Interpretation - S.Y., Y.G.; Literature Search - S.Y., Y.G.; Writing - S.Y., Y.G.; Critical Reviews - S.Y., Y.G.

Conflict of interest statement: The authors declare that there are no conflicts of interest.

\section{REFERENCES}

[1] Manova E, von Goetz N, Hauri U, Bogdal C, Hungerbuhler K. Organic UV filters in personal care products in Switzerland: A survey of occurrence and concentrations. Int J Hyg Envir Health. 2013; 216 (4):508-514.

[2] Sharma A, Bányiová K, Babica P, El Yamani N, Collins AR, Čupr P. Different DNA damage response of cis and trans isomers of commonly used UV filter after the exposure on adult human liver stem cells and human lymphoblastoid cells. Sci Total Environ. 2017; 593-594 (1):18-26.

[3] Sarveiya V, Risk S, Benson HAE. Liquid chromatographic assay for common sunscreen agents: application to in vivo assessment of skin penetration and systemic absorption in human volunteers. J Chromatogr B Analyt Technol Biomed Life Sci. 2004; 803(2):225-231.

[4] Gilbert E, Pirot F, Bertholle V, Roussel V, Falson F, Padois K. Commonly used UV filter toxicity on biological functions: review of last decade studies. Int J Cosmet Sci. 2013; 35(3):208-219.

[5] Fent K, Kunz PY, Zenker A, Rapp M. A tentative environmental risk assessment of the UV-filters 3-(4methylbenzylidene-camphor), 2-ethyl-hexyl-4-trimethoxycinnamate, benzophenone-3, benzophenone-4 and 3benzylidene camphor. Mar Environ Res. 2010; 69(1):S4-S6.

[6] Klimová Z, Hojerová J, Pažoureková S. Current problems in the use of organic UV filters to protect skin from excessive sun exposure. Acta Chimica Slovaca.2013;6(1):82-88.

[7] Chisvert A, Pascual-Marti MC, Salvador A. Determination of UV-filters in sunscreens by HPLC. Fresenius J Anal Chem. 2001; 369(7-8):638-641.

[8] Kim TH, Shin BS, Kim KB, Shin SW, Seok SH, Kim MK, Kim EJ, Kim D, Kim MG, Park ES, Kim JY, Yoo SD. Percutaneous absorption, disposition, and exposure assessment of Homosalate, a UV filtering agent, in rats. J Toxicol Environ Health. 2014; 77(4):202-213.

[9] Diaz-Cruz MS, Gago-Ferrero P, Llorca M, Barcelo D. Analysis of UV filters in tap water and other clean waters in Spain. Anal Bioanal Chem. 2012; 402(7):2325-2333.

[10] Gago-Ferrero P, Diaz-Cruz MS, Barcelo D. Fast pressurized liquid extraction with in-cell purification and analysis by liquid chromatography tandem mass spectrometry for the determination of UV filters and their degradation products in sediments. Anal Bioanal Chem. 2011; 400(7):2195-2204.

[11] Schlumpf M, Kypke K, Wittassek M, Angerer J, Mascher H, Mascher D, Vokt C, Birchler M, Lichtensteiger W. Exposure patterns of UV filters, fragrances, parabens, phthalates, organochlor pesticides, PBDEs, and PCBs in human milk: correlation of UV filters with use of cosmetics. Chemosphere. 2010; 81(10):1171-1183.

[12] Valle-Sistac J, Molins-Delgado D, Diaz M, Ibanez L, Barcelo D, Silvia Diaz-Cruz M. Determination of parabens and benzophenone-type UV filters in human placenta. First description of the existence of benzyl paraben and benzophenone-4. Environ Int. 2016; 88:243-249.

[13] Gasparro FP, Mitchnick M, Nash JF. A review of sunscreen safety and efficacy. Photochem Photobiol. 1998; 68(3):243256.

[14] Directive C. 76/768/EEC. Based on the Commission Staff Working Document:Timetables for the Phasing-out of Animal Testing in the Framework of the 7th Amendment to the Cosmetic, 1976. http://ec.europa.eu/consumers/sectors/cosmetics/files/doc/antest/sec_2004_1210_en.pdf (accessed 27 March, 2017).

[15] Krause M, Klit A, Jensen MB, Soeborg T, Frederiksen H, Schlumpf M, Lichtensteiger W, Skakkebaek NE, Drzewiecki KT. Sunscreens: are they beneficial for health? An overview of endocrine disrupting properties of UV-filters. Int J Androl. 2012; 35(3):424-436.

[16] Shaath NA. Sunscreens: Regulations and Commercial Development. Cosmetic science and technology series. Third ed. Taylor\&Francis Group, Boca Raton, London, 2005. 
[17] Li Y, Qu M, Sun L, Wu Y, Chen Y, Chen H, Kong Z, Liu Z. Genotoxicity study of phenol and $o$-cresol using the micronucleus test and the comet assay. Toxicol Environ Chem. 2005; 87(3):365-372.

[18] Maistro EL, Angeli J, Andrade S, Mantovani M. In vitro genotoxicity assessment of caffeic, cinnamic and ferulic acids. Genet Mol Res. 2011; 10(2):1130-1140.

[19] Anderson D, Yu TW, Hincal F. Effect of some phthalate esters in human cells in the comet assay. Teratog Carcinog Mutagen. 1999; 19(4):275-280.

[20] Erkekoglu P, Koçer-Gümüssel B. Genotoxicity of phthalates. Toxicol Mech Method. 2014; 24(9):616-626. http://dx.doi.org/10. 3109/15376516.2014.960987.

[21] Šrut M, Traven L, Štambuk A, Kralj S, Žaja R, Mićović V, Klobučar GI. Genotoxicity of marine sediments in the fish hepatoma cell line PLHC-1 as assessed by the Comet assay. Toxicol In Vitro. 2011; 25(1):308-314.

[22] Smith DA. Metabolism, pharmacokinetics, and toxicity of functional groups: impact of the building blocks of medicinal chemistry in ADMET. In: Dalvie D, Nair S, Kang P, Loi CM. (Eds). Influence of Aromatic Rings on ADME Properties of Drgs. Royal Society of Chemistry. 2010;pp.275-327.

[23] Urek SY, Bilgin M, Halli BU. Toxicological profile of homosalate as cosmetic ingredients. Global J Pathol Microbiol. 2013:1;7-11.

[24] Zhao H, Wei D, Li M, Du Y. Substituent contribution to the genotoxicity of benzophenone-type UV filters. Ecotoxicol Environ Saf. 2013; 95:241-246.

[25] Terrazas PM, de Souza Marques E, Mariano LN, Cechinel-Filho V, Niero R, Andrade SF, Maistro EL. Benzophenone guttiferone A from Garcinia achachairu Rusby (Clusiaceae) presents genotoxic effects in different cells of mice. PloS One. 2013; 8(11): e76485.

[26] Cuquerella MC, Lhiaubat-Vallet V, Cadet J, Miranda MA. Benzophenone photosensitized DNA damage. Acc Chem Res. 2012; 45(9):1558-1570.

[27] Serpone N, Dondi D, Albini A. Inorganic and organic UV filters: Their role and efficacy in sunscreens and suncare products. Inorg Chim Acta. 2007; 360(3):794-802.

[28] Nohynek GJ, Schaefer H. Benefit and risk of organic ultraviolet filters. Regul Toxicol Pharmacol. 2001; 33(3):285-299.

[29] Downs C, Kramarsky-Winter E, Fauth JE, Segal R, Bronstein O, Jeger R, Lichtenfeld Y, Woodley CM, Pennington P, Kushmaro A. Toxicological effects of the sunscreen UV filter, benzophenone-2, on planulae and in vitro cells of the coral, Stylophora pistillata. Ecotoxicol. 2014; 23(2):175-191.

[30] Imamoviä B, Mušanoviä J, Beäiä E, Šober M. Investigation of genotoxicity of Homosalate byproducts occurred in the presence of free chlorine by using Allium Test. Int J Collab Res Intern Med Public Health. 2016; 8(8):472-482.

[31] Sevinc D. Ms Thesis. Investigation of the cytotoxic and genotoxic effects of some sunscreen compounds on healthy cell culture. Department of Biology, Graduate School of Natural and Applied Sciences, Uludag University, Bursa, Turkey, 2014.

[32] Singh NP, McCoy MT, Tice RR, Schneider EL. A simple technique for quantitation of low levels of DNA damage in individual cells. Exp Cell Res. 1988; 175(1): 184-191.

[33] Collins AR, Dusinska M, Gedik CM, Stetina R. Oxidative damage to DNA: do we have a reliable biomarker? Environ Health Persp. 1996;104(3):465-469. 